\title{
A Armação Baleeira de Garopaba: sua justa dimensão
}

\author{
The Whaling Frame of Garopaba: your fair dimension
}

\author{
João Pacheco de Souza* \\ Roberta Barros Meira**
}

\begin{abstract}
Resumo: Este texto se propõe a discutir a Armação Baleeira de Garopaba, pertencente ao complexo de armações construídas e exploradas no Brasil entre os séculos XVII e XIX. Privilegia aspectos relacionados à fundação e à estrutura da Armação, isto é, um sistema organizado de caça da baleia, produção e distribuição de óleo que desempenhou um papel ativo no processo de formação do município de Garopaba. A análise que se segue considera não só a importância econômica da produção do óleo da baleia, mas enfatiza o seu papel primordial ao imprimir um ritmo próprio à economia de algumas regiões coloniais. Nesse sentido, pretende-se dialogar com a historiografia existente, ressaltando a pouco discutida relação entre as armações e a instalação de uma sucessão regular de centros povoados, que se mantinham no litoral catarinense.
\end{abstract}

Palavras-chave: Armação Baleeira; Garopaba; povoamento.

Abstract: This text proposes to discuss the Whaling Frame Garopaba, part of the complex built frames and explored in Brazil between the XVII and XIX. Focuses on aspects related to the foundation and the frame structure, that is, an organized system of whale hunting, production and distribution of oil that played an active role in the formation of the municipality of Garopaba. The following analysis considers not only the economic importance of whale oil production but considers its primary role when printing their own pace to the economy of these colonial regions. In this sense, we intend to dialogue with the

\footnotetext{
* Técnico em assuntos educacionais do Instituto Federal de Educação, Ciência e Tecnologia de Santa Catarina, Florianópolis/SC, Brasil. E-mail: joaopachecosouza@gmail.com

** Docente do Mestrado em Patrimônio Cultural e Sociedade e do Departamento de História da Universidade da Região de Joinville - Univille, Joinville/SC, Brasil. E-mail: rbmeira@gmail.com
}

(c) EY Direito autoral e licença de uso: Este artigo está licenciado sob uma Licença Creative Commons. Com essa licença você pode compartilhar, adaptar, para qualquer fim, desde que atribua a autoria da obra, forneça um link para a licença, e indicar se foram feitas alterações. 
existing historiography, highlighting the little-discussed relationship between the frames and the installation of a regular succession of population centers that remained in the Santa Catarina coast.

Keywords: Whaling frame; Garopaba; population

\section{Introdução}

Em obra clássica de 1627, Frei Vicente de Salvador ${ }^{1}$ afirmava que era muito proveito que se tirava com a caça da baleia. O aproveitamento desse produto era essencial não só para o mercado externo, mas para a utilização na própria Colônia, tanto para reboque dos navios, construções e, principalmente, iluminação. Certo é que esse produto contribuiu para estimular o mercado interno, a construção naval, a ocupação e o crescimento de algumas regiões. Por outro lado, é de lembrar que essa configuração peculiar de fatores é tema ainda marginal na historiografia. ${ }^{2}$

Dessa extensa rede de armações, a Armação Baleeira de Garopaba, a que mais nos interessa aqui, apresentou amplos recursos em material utilizado na caça, equipamentos destinados ao beneficiamento, além do emprego de mão-de-obra especializada ou não. Nesse sentido, propõe-se a discutir a importância local dessas armações, partindo do argumento que a construção e a exploração dos produtos da baleia criou novos espaços econômicos em regiões consideradas como periféricas pela Coroa portuguesa.

De fato, a Armação Baleeira São Joaquim de Garopaba fez parte de um projeto maior que envolveu uma rede de Armações Baleeiras pelo Brasil, as quais formavam complexas unidades de produção e de beneficiamento de óleo de baleia. Como se sabe, a palavra "armação" tem sua expressão originada em armar para a pesca; armar às baleias, ou seja, equipar-se para a pesca das baleias. Segundo Saint-Hilaire 3 , "armação é o nome que é dado aos estabelecimentos de onde partem os barcos que vão à pesca e para onde são trazidas as baleias a fim de lhes ser extraídas o óleo". Nesse sentido, também podem ser consideradas "núcleos ou feitorias de pesca e manufatura de óleo de baleia", ou melhor, "termo designativo de aparelhamento permanente em locais apropriados para a pesca litorânea, passou a definir, no Brasil-Colônia, a feitoria baleeira que promovia a captura dos cetáceos e o beneficiamento do óleo de baleia"4. Certo é que armação baleeira foi uma designação usada não só para explicar o local onde as baleias eram desmanchadas, mas dizia respeito a tudo aquilo que compunham a grande empresa de caça. ${ }^{5}$

Sabe-se que o início da pesca da baleia no Brasil ocorreu através de Pero de Urecha e mais biscainhos, oriundos de Biscaia, litoral da Espanha. Ao aportar em 1602, na Bahia, tornaram-se os responsáveis pela introdução e circulação de técnicas no Brasil. Teriam aprendido tais habilidades com os 
normandos durante a Idade Média desde o século IX. A pesca em Biscaia teria se iniciado antes do século XIII. Portanto, como aclara Ellis, "a costa basca, que se estende de Baiona a Bilbao, localizada no Golfo de Gasconha é tida como o berço da indústria, que no passado foi a pesca da baleia". ${ }^{6}$ As Armações Baleeiras que existiram na Bahia, Rio de Janeiro, São Paulo e Santa Catarina foram importantes para a Coroa Portuguesa como fonte de renda, mecanismo de ocupação e posse do território, manifestação da presença do Rei, além de sua finalidade especifica que era a produção do óleo e outros derivados do cetáceo. Esse cunho oficial que abarcava diversas partes do Império português não significa esquecer os impactos locais derivadas do incremento desse complexo industrial que tinham como base a exploração da caça das baleias.

\section{A arte complexa de produzir óleo de baleia no Brasil}

Essas estruturas produtivas monumentais configuraram-se como um tipo de empreendimento com alto grau de sofisticação, pois reuniam no mesmo espaço elevado número de ocupações especializadas e uma significativa força de trabalho, que atuavam no espaço marítimo e terrestre. Desde o início, foram pensadas para produzir em larga escala. A definição do local para a instalação das armações baleeiras levava em conta fatores como: a existência de água em boa quantidade, disponibilidade de madeira, as condições para o plantio de mandioca e criação de animais, o clima e as correntes marítimas, a profundidade mínima do mar nas proximidades da praia para a manobra dos barcos e proteção dos ventos. Como não poderia deixar de ser, o mais relevante era a presença das baleias. Mas, um outro aspecto importante a ser destacado seria o fato da instalação das armações provocar a formação de núcleos populacionais que demarcaram diversos pontos do litoral brasileiro e deram origem ou foram determinantes na formação de diversas localidades, como foram os casos de Armação da Piedade, Governador Celso Ramos/SC; Penha/SC; Itaparica/BA; Búzios/RJ e Garopaba/SC, entre outras ${ }^{7}$.

Aliás, as armações baleeiras foram empreendimentos que apresentaram várias facetas. Dentre elas, uma foi ter sido monopólio régio, quando a baleia passou a ser considerado peixe-real, ou seja, uma propriedade da Coroa. O monopólio significava o direito exclusivo do Rei de comercializar. Fazia parte da política econômica e possibilitava o deslocamento do capital da Colônia para a Metrópole. No caso da pesca da baleia, a concessão garantia exclusividade da pesca, manufatura do óleo, do abastecimento da metrópole e do comércio dos seus produtos. O monopólio se efetivava através de um assento ou contrato em que se estabeleciam as obrigações e privilégios das partes contratantes: a Coroa e os contratadores. Ao final do contrato, todo o patrimônio das armações passou a ser propriedade da Fazenda Real. ${ }^{8}$

Os recursos obtidos pela Coroa com os contratos tinham várias destinações, em sua maior parte destinados à manutenção das estruturas 
de governo na Colônia, como o pagamento de pessoal, aquisição de mantimentos, operações militares e demais ações de governo. As armações constituíam assim importante fonte de renda para o funcionamento dos órgãos administrativos da Coroa. Entre os privilégios estabelecidos nos contratos destaca-se o tratamento diferenciado aos contratadores, tidos como servidores do Real Monopólio. Os laços comerciais e de sociabilidade que se estabeleciam entre os contratadores e a elite governante criava condições para se firmar relações de compadrio, o que facilitava a obtenção de benesses que geravam distinções no meio social e também permitiam um maior controle por parte da Coroa. ${ }^{9}$

Uma das características marcantes da construção das armações era a necessidade de um expressivo aporte de recursos e a obediência a um plano de engenharia. Ora, era necessário que as estruturas localizadas à beira mar garantissem a continuidade das atividades da pesca das baleias iniciadas no mar. Destacam-se, nesse caso, nas armações baleeiras os trapiches, rampas, paredões, engenhos de frigir, engenhos da casa dos tanques, armazéns, depósitos, enfermaria, capela e residências. Deve-se considerar assim a importância dada aos engenhos de frigir azeite ou fábricas, pois neles ocorria o processamento da baleia. Como afirma Ellis ${ }^{10}$, "era o principal setor da armação, centro nevrálgico que concorria e para o que compareciam os trabalhos cotidianos". A casa dos tanques era destinada para armazenar o óleo. Junto à fábrica e casa dos tanques, existiam construções destinadas à venda do azeite, armazenamento de barbatanas, depósito de pipas e barris utilizados no acondicionamento do óleo de baleia. Nas proximidades encontravam-se as edificações destinadas à residência da população baleeira, as dedicadas aos cuidados da saúde, às práticas religiosas e também as destinadas à administração da Armação. As residências expressavam uma divisão social, uma hierarquia, presente na população baleeira: As senzalas eram destinadas aos escravos e as companhas de baleeiros serviam para a residência dos remeiros, timoneiros e arpoadores. Na casa dos feitores se hospedavam aqueles que assessoravam o administrador da Armação e a casa do administrador que além de residência, servia de depósito e de hospedagem.

Podem-se caracterizar as atividades realizadas nas armações durante o ano em duas etapas: período da pescaria das baleias, entre junho e outubro; e o período de manutenção das instalações, atividades agrícolas e corte de lenha, e as atividades que duravam o restante do período anual. No dia de Santo Antônio ou São João se realizava a missa para sinalizar o início das atividades da pescaria. $\mathrm{O}$ padre se dirigia à praia para a benção dos pescadores e dos instrumentos que eram empregados na captura e transportes das baleias. ${ }^{11}$ A missa simbolizava a conexão com o divino para que o enfrentamento com os gigantes do mar fosse favorável aos homens e que a força divina estivesse presente nesta labuta. ${ }^{12}$ 
As baleias procuravam os remansos e reentrâncias das baías e enseadas para sua reprodução, parturação e amamentação. A pesca das baleias envolvia diversas embarcações com funções determinadas e equipamentos utilizados no enfrentamento com as baleias visando a sua matança. A tripulação, chefiada pelo arpoador, contava com um auxiliar imediato e com os remeiros, em número de oito habitualmente, responsáveis pela condução e manobra das baleeiras na luta com as baleias. A pescaria consistia na aproximação da baleia e na utilização do arpão e de lanças que eram arremessados para matá-las. Exigia perícia e muita agilidade por parte da tripulação para garantir o sucesso na luta. Vencida a baleia, a etapa seguinte consistia em transportá-la para a praia, o que exigia uma série de cuidados e presteza. Os trabalhos de despostejamento das baleias envolvia outro conjunto de trabalhadores que atuavam no desmanche da baleia e o seu transporte para o engenho de frigir. As partes aproveitadas do cetáceo eram o toucinho, do qual se produzia o óleo de baleia, as barbatanas, os ossos e a carne. ${ }^{13}$

O processamento das baleias era realizado pelos escravos de forma ininterrupta. O trabalho era estafante e contínuo para que se pudesse aproveitar ao máximo as partes da baleia, que expostas ao ar se decompunham com rapidez, além de exalarem um cheiro muito forte e nauseante. Somava-se, ainda, uma grande produção de fumaça. Evidencia-se desta forma o caráter de exploração a que eram submetidos os trabalhadores nesse processo. ${ }^{14} \mathrm{~A}$ produção do óleo ocorria através de técnicas simples. Consistiam basicamente na manipulação da gordura e na manufatura do óleo. Porções de toucinho eram levadas às fornalhas sobre as quais estavam instaladas as caldeiras onde se cozinhava o toucinho. $\mathrm{O}$ óleo destinado à iluminação era utilizado em velas, tigelinhas de barro, lamparinas, lampiões, que eram aparelhos de iluminação. O óleo alimentava um fio de algodão, chamado pavio, que ao queimar provocava o brilho da chama.

Os ossos tinham aplicações como objeto de decoração, móveis e assentos dos bancos, mesas, base para lavar roupas e também para a proteção de plantações. ${ }^{15}$ A carne da baleia tinha ampla utilização como alimento dos escravos e da população mais pobre. ${ }^{16} \mathrm{~A}$ barbatana passava por um processo de limpeza e de secagem e era enfardada para exportação para Europa, onde era utilizada em várias manufaturas. ${ }^{17} \mathrm{O}$ óleo servia para a saboaria, curtume e construções para a confecção de argamassa utilizada como liga. Mas, a maior aplicação do óleo ou azeite era na iluminação. ${ }^{18}$ Ademais, era utilizado para iluminação de engenhos, vias públicas, oratórios, presídios, quartéis, fortalezas, hospitais, barcos, câmaras de vereadores, além das moradias. Além disso, o óleo tornou-se essencial para a produção em maior escala do açúcar e da farinha de mandioca ao não restringir a produção ao período diurno. Vê-se, assim, facilmente, a sua importância na economia colonial da América Portuguesa. De fato, o seu declínio só ocorreu pela redução do número de baleias no litoral 
brasileiro, pela concorrência das empresas internacionais presentes no litoral brasileiro e por fim da descoberta do petróleo, que barateou as despesas com a iluminação. ${ }^{19}$

As discussões em torno das Armações Baleeiras e da caça das baleias no Brasil tratam na sua grande maioria do Período Colonial. Estes estudos caracterizam-se por privilegiar as questões de fundo econômico relacionadas à produção de derivados da baleia, em especial do óleo ou azeite de baleia, fonte de valiosos recursos financeiros nestes séculos para a Coroa Portuguesa. Demais, os derivados da baleia constituíram importantes produtos de exportação, em especial o óleo e as barbatanas. Nesse sentido, é perfeitamente natural que os estudiosos que se ocuparam desta temática enfatizem justamente o lado econômico das Armações Baleeiras, principalmente a relação do óleo da baleia com a iluminação e a construção. Mas, há que se ter em conta que as Armações constituíram importantes núcleos populacionais, ou seja, tiveram participação efetiva na ocupação de faixas importantes do litoral e serviram de base para a formação de várias localidades que passaram a integrar a população da Colônia.

\section{Uma parte do todo: a Armação Baleeira de Garopaba}

A fundação da Armação Baleeira de Garopaba ocorreu entre os anos de 1793 e 1795. O contrato das baleias em vigência havia sido assinado para o período 1789 - 1801, tendo como contratantes principais Pedro Quintela e Luís Sola. O valor do contrato foi de 120 mil cruzados anuais e abrangia todas as Armações da Costa Brasileira. Até 1789 existiam em Santa Catarina três Armações: A Armação da Piedade instalada em Santa Catarina, em torno de 1743-1745, a segunda teve sua instalação na Lagoinha, na costa leste da Ilha de Santa Catarina em 1772 e a terceira localizava-se onde atualmente é o município de Penha. Aliás, esta Armação denominada Itapocoroy foi instalada em 1788, sendo que a principal motivação foi à invasão da Ilha de Santa Catarina, em 1777, pelos espanhóis. Assim, não seria como um caso isolado que a Armação de Garopaba foi erguida. Tendo apenas alguns anos de diferença das suas congêneres foi construída e funcionou, em seu período inicial, durante o contrato com Quintela e associados que administravam todas as Armações do Brasil Meridional.

Exemplo da premente urgência de ocupar a região é a correspondência enviada pelo Rei de Portugal ao Governador do Rio de Janeiro em 1717. Justifica-se, nesse sentido, a insistência na requisição de informações que possibilitassem examinar as qualidades do litoral e, consequentemente, a segurança das embarcações, a abundância de peixes, a possibilidade de pesca de baleias e se o povoamento do dito distrito poderia ser de valia para a nova colônia. ${ }^{20}$ Aliás, pode-se considerar que o projeto de ocupação do Brasil Meridional se concretizou com a criação da Colônia do Sacramento em 1638, e da Capitania 
de Santa Catarina em 1738. Chama a atenção, nesse momento, a vinda de Silva Paes para a Ilha de Santa Catarina para estabelecer as bases militares e condições para o estabelecimento dos açorianos entre 1748-1754. Ora, neste sentido, a instalação das Armações de Piedade, de Lagoinha do Leste, de Itapocoroy e a de Garopaba e seu complemento em Imbituba podem ser consideradas como empreendimentos que contribuíram para o processo de ocupação, defesa e povoamento da região. Mais ainda, era uma parte estruturante do projeto que atender a necessidade de geração de renda para a Coroa.

Seria lícito supor nesse quadro que a Armação Baleeira de Garopaba cumpriu importantes funções para atender a estratégia acima mencionada de ocupação e posse do Brasil Meridional além de promover condições no sentido de fortalecer a economia local. É de se lembrar de que o período de 1793-1795 faz parte da consolidação do projeto de colonização de Santa Catarina com a vinda dos açorianos para o sul do Brasil. Garopaba nesta época fazia parte da Freguesia de Nossa Senhora do Rosário da Enseada de Brito, criada em 1750. Ao que se saiba, já se constituía em um ponto importante para aguada e repouso para as tripulações e viajantes que ali transitavam para Laguna ou Rio da Prata ou no sentido contrário para Desterro ou Rio de Janeiro, tendo em conta que os acessos por terra eram precários. ${ }^{21}$

O nome Garopaba, segundo Boiteux ${ }^{22}$, se origina de nomes indígenas. Ygara significa lagoa e upaba, canoa. Então, lagoa da canoa. Segundo o padre Besen este nome vem grafado - Cahopaba - na Carta de Turim, em 1523, pela primeira vez. Ou assim: Upaua, Upaba, Guarupeba. Muitos veem neste nome o significado de "Enseada das Garoupas". O verdadeiro significado está no Guarani, a língua local: Ygá, Ygara, Ygaratá que significa barco, embarcação, canoa; mpaba, paba é estância, paradeiro, lugar, enseada. Garopaba então significa "Lugar dos Barcos", "Enseada dos Barcos". ${ }^{23}$

É preciso que se atente que Garopaba ${ }^{24}$ se inseriu no processo de ocupação do litoral catarinense a partir do século XVII, com a expansão do Império Português em direção ao Rio da Prata, quando são instalados os primeiros núcleos de povoamento. Destaca-se a presença de Brito Peixoto que pelo que se sabe se instalou onde atualmente é a Enseada de Brito, cujo nome seria uma homenagem a ele. ${ }^{25}$ Domingos de Brito Peixoto teria permanecido por um período em Enseada de Brito, de onde se deslocou para fundar Laguna. Segundo Paulo José Miguel de Brito, a Freguesia:

oferece um bom ancoradouro e abrigo aos navios é situada na costa da Terra firme defronte do canal da barra do sul da capital. Foi seu fundador Domingos de Brito Peixoto, que no ano de 1652 veio de Santos, daí chamar-se Enseada de Brito. O local é plano e vistoso e perto se eleva a serra do Cambirela da qual se precipitam cachoeiras de excelente água potável. É farta de peixe, cultiva-se aí cana-de-açúcar, 
mandioca, café e legumes. Suas matas encerram boas madeiras de construção e marcenaria. Povoação pequena situada na terra firme à beira-mar sobre a costa fronteira à ponta de Caiacangoassu, na Ilha, e quase leste-oeste com a mesma ponta. A igreja é pequena e antiga, dedicada à N.S. do Rosário, e tem um vigário. O limite desta Freguesia pelo norte chega a duas léguas, até o rio Aririú, por onde extrema com a Freguesia de São José; e pelo sul avança a seis léguas até o lugar chamado Páo da Rainha, nos matos de Garopaba. A sua população compunha-se de 1511 almas, distribuídas em 555 homens brancos, 569 mulheres brancas, escravos homens 289 e mulheres $98 .{ }^{26}$

A vida econômica na Freguesia era basicamente voltada para o mercado local, que se expressava principalmente pela produção de farinha de mandioca e pela pesca artesanal. Os batismos, os casamentos, as festas religiosas e os atos relativos à morte constituíam o centro da vida social em que ocorria o convívio social, o namoro, os negócios, os espaços para o exercício das lideranças, ou melhor, a vida social, era centralizada pela Igreja Católica. A grande maioria da população vivia na pobreza e os poucos que detinham uma melhor condição, assumiam a liderança, seja na vida religiosa como padrinhos, festeiros, dirigentes das confrarias, seja na vida civil como juiz de paz, subdelegado de polícia ou militar graduado das forças militares. ${ }^{27}$ Neste contexto é que Garopaba vai ser povoada.

A instalação da Armação de Garopaba, e seu complemento em Imbituba, ocorrem pelas razões gerais indicadas acima. Mas, não se tem uma versão que explique as possíveis motivações dos contratadores. Ao que se saiba, tal iniciativa pode estar relacionadas à manutenção dos lucros perdidos pelos contratadores com a invasão espanhola da Ilha de Santa Catarina, em 1777. Além disso, pode-se considerar plausível a necessidade de ampliação da área de pesca para fazer frente à redução crescente de baleias no litoral catarinense. Soma-se a estas hipóteses, a concorrência enfrentada com as companhias estrangeiras. Aliás, outro aspecto que se conjuga com o projeto de defesa e ocupação do território no Brasil Meridional é a condição de Garopaba e Imbituba como pontos estratégicos do litoral. Estes locais possibilitavam acesso à terra em boas condições, pois eram os únicos pontos, além de Laguna entre a Ilha de Santa Catarina e o Rio Grande do Sul que oferecem condições propícias para embarque e desembarque de embarcações para reparos, aguada e descanso das tripulações.

Não há consenso quanto à data da instalação da Armação. Há indicações referentes tanto ao ano de 1793 quanto ao de 1795. Dentre os manuscritos consultados mais expressivos para esse trabalho encontra-se o intitulado: "Memória sobre a notícia das Armações de baleias que até o fim do ano de 1794 
havia na Ilha de SC, terra firme, costa do Brasil e sobre o estado da pescaria das baleias até 1794", cujo autor não é identificado. O referido documento apresenta um relato sobre a situação das Armações da Ilha de Santa Catarina até 1794. Mencionava, demais, as Armações da Piedade, da Lagoinha e de Itapocoroy, destacando aspectos de cada uma. ${ }^{28}$

É não é ao acaso que o autor descreveu e apontou várias questões relacionadas à criação e a instalação da Armação de Garopaba. Assim, como a ênfase no fato de que João Marcos Vieira foi o responsável pela decisão e pela implantação da Armação de Garopaba. Acrescenta-se a tudo isso, a posição contrária do autor à construção da Armação de Garopaba, indicando como causa para a sua instalação os interesses escusos de João Marcos Vieira. Argumentava que o local, no caso Garopaba, era impróprio e prejudicial às demais Armações. No mais, aclarava que em 1798 ocorreu uma redução do número de baleias pescadas e a redução de remeiros e arpoadores na pescaria. As indicações do autor apontam para o ano de 1793 como o início das obras e 1795 como o período para sua conclusão, em vista da ida de João Marcos Vieira para o Rio de Janeiro. Apesar deste posicionamento, a Armação Baleeira de Garopaba e seu suplemento de Imbituba foram construídos, sendo incorporados ao complexo de exploração baleeiro. ${ }^{29}$ Vale ressaltar o posicionamento exacerbado do autor anônimo contra a construção de uma armação em Garopaba:

Até o anno de 1794 havião naquele destricto, somente três Armaçoens: duas da parte de Leste, na Costa da Terra firme, e huma da parte de Leste na contra costa da Ilha. Este hera o estado em que se achavam as três Armaçoens, no fim do anno de 1794 tendo João Marcos Vieira Administrador da primeira Armação passado já por acesso em 1793 para a Capital do Rio de Janeiro, a servir de segundo Caixa e Administrador Geral, de todo o mesmo Contracto [...] Agora se fará menção da Armação de Garupaba, e Fábrica de Imbituba, obra inteiramente innutil, e feita maliciosamente por João Marcos Vieira, como abaixo se expoem: O mau caráter deste homem é sumamente raro, [...] João Marcos Vieira já antes de partir para o Rio de Janeiro tinha falado em huma Armação, no lugar de Garupaba, que fica na Terra firme [...] que mais hera para estender seu nome, do que para interessar o contracto, ou para até fazer ponto, para o que lhe fosse útil, como he o seu constume [...] Até que João Marcos passou para o Rio de Janeiro, em fins do mês de Agosto de 1793, ficando isto em silêncio até o fim do anno de 1794, e só no anno de 1795, he que até se vencerão impossíveis para fazer a Armação de Garupaba, mas he porque esta obra, hera para outro fim $[\ldots] .^{30}$ 
Também no manuscrito, o autor discorreu sobre a apreensão de um navio de propriedade de João Marcos Vieira por parte do Provedor da Fazenda. Demais, esse episódio teria o envolvimento do Governador Manoel Soares Coimbra. Aliás, o provedor com o apoio do Comandante da fortaleza de Santa Cruz, Manoel Alves Varela declarou posteriormente o confisco do navio. Um exemplo de tal querela pode ser visto na citação de um segundo trecho do referido documento.

João Marcos Vieira apetrestos de vir passar a Santa Catharina, para o fim de fundar, a Armação de Garupaba, tão innútil e prejudicial, que para pescar alguma cousa, lhe foy percizo fundar mais para o sul della, huma Feitoria, no lugar de Imbituba e a vista do referido, parece que ao pagamento de semelhantes obras, não deve ser obrigada a Fazenda de sua Alteza Real, não obstante as condiçoens $7^{\mathrm{a}}, 8^{\mathrm{a}}$ e $9^{\mathrm{a}}$ do Contracto, que não devem comprehender, as obras feitas por malícia, ou interesse particular, como já foy decedido, em semelhante cazo, pelo Provizão Régia de $1773 .{ }^{31}$

Segue o documento discorrendo sobre a apreensão do navio e prisão de João Marcos Vieira, que por ser Administrador do contrato das baleias obteve autorização para vir para Santa Catarina, para a conclusão da Armação de Garopaba. Além disso, relatou as medidas prejudiciais à pesca das baleias nas outras Armações devido à transferência de caldeiras, lanchas e escravos para a Armação de Garopaba. Outra medida prejudicial foi a redução do salário dos baleeiros "remeiros e arpoadores" que redundou na diminuição do pessoal na pescaria e em consequência reduziu o número de baleias pescadas. Embora, o autor anônimo levante uma série de motivos para evitar a construção da Armação e, posteriormente, dos seus problemas, o que mais nos interessa aqui são os indícios de uma concorrência pela obtenção da exploração de uma atividade que propiciava altos dividendos, gerando inúmeras queixas frente à atuação dos beneficiários.

É preciso não esquecer que dentre os documentos relacionados à Armação de Garopaba pode-se destacar a pintura feita por Jean-Baptiste Debret (figura 2). $\mathrm{O}$ pintor francês ao retratar as riquezas do país nascente traz uma perspectiva das instalações, assim como a localização espacial da Armação. Assim, como deve merecer atenção a Planta de Localização da Armação de Garopaba (figura 1), encomendado pelo governador da Ilha de Santa Catarina, Miranda Ribeiro. A planta contém ainda uma legenda relacionando e identificando as obras. É preciso que se considere que, nesse caso, tanto o registro iconográfico como cartográfico podem servir como atestados de sua localização e bases para formar uma ideia de suas dimensões e disposição espacial. ${ }^{32}$ 


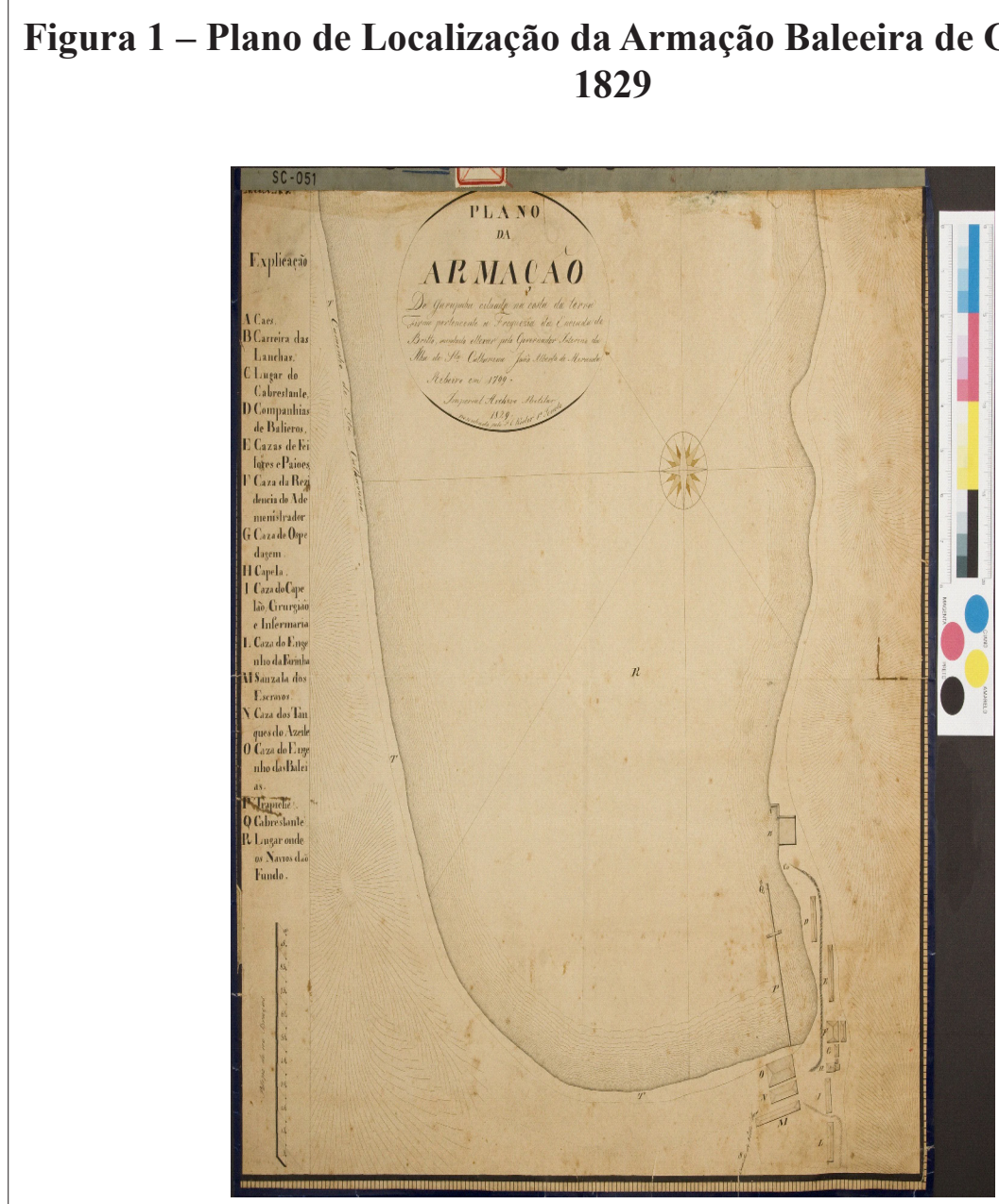

Fonte: Arquivo do Exército. Rio de Janeiro

Figura 2 - Quadro de Debret retratando a Armação de Garopaba

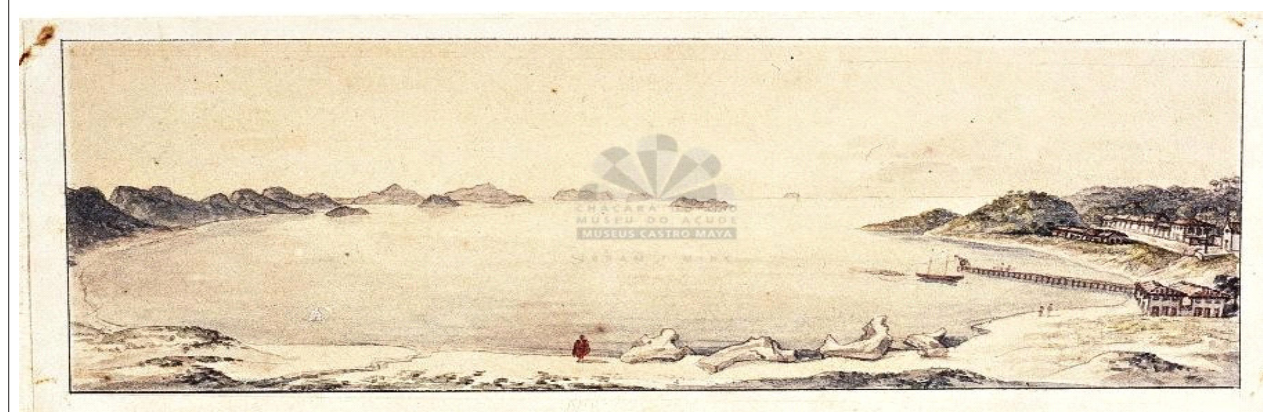

Fonte: Museu Castro Maya. Rio de Janeiro. 
Ainda com relação ao tamanho da Armação pode-se contar com o Inventário da Armação feito em 1816. Como se pode identificar na tabela 1 e nas figuras 1 e 2 o conjunto das instalações era significativo e cumpriam funções importantes.

\section{Quadro 1 - Inventário da Armação Baleeira de Garopaba realizado de 1816}

\begin{tabular}{|l|l|}
\hline Edificações e Estruturas & Equipamentos e utensílios \\
\hline Capela & Lanchas e Canoas \\
\hline Casa de vivenda & Trapiche \\
\hline Armazém & Caldeiras \\
\hline Casa do Hospital & Ferragens e ferramentas \\
\hline Senzala dos escravos & Terrenos \\
\hline Casa dos Feitores & \\
\hline Casa do Engenho de Frigir baleias & \\
\hline Casa dos tanques & \\
\hline Campanhas das Baleeiras & \\
\hline Paredes e Cais de pedra & \\
\hline Casas cobertas de palha & \\
\hline
\end{tabular}

Fonte: Arquivo Nacional, Caixa $360 .^{33}$

As edificações como a Casa de Engenho de Frigir Baleias, Casa dos Tanques, Campanhas das Baleeiras, Paredes e Cais de Pedra e seus respectivos equipamentos e ferramentas eram destinados ao trabalho de despostejamento da baleia e processamento do óleo, atividade central da Armação. A Capela, Casa de Hospital, constituíam espaços para as práticas religiosas e de saúde. A Casa de Vivenda, Senzala dos Escravos, Casa dos Feitores, Companhas de Baleeiros eram espaços destinados à residência da população baleeira. $\mathrm{O}$ Armazém era utilizado para depósito de alimentos e demais recursos necessários para atividades cotidianas e as Casas cobertas de palha abrigavam. ${ }^{34}$

Ainda havia o sítio da fazenda e o cemitério como espaços importantes da Armação. O Inventário apresenta ainda uma relação de escravos, além de revelar detalhes como medidas de comprimento, altura e largura das edificações e seus respectivos valores avaliados por pedreiros e por carpinteiros. A relação acima mencionada possibilita dimensionar a complexidade e a grandiosidade da Armação Baleeira de Garopaba. ${ }^{35}$ Pode-se deduzir das informações acima mencionadas que a Armação Baleeira de Garopaba apresenta dimensões 
consideráveis e certamente provocaram impacto no local onde funcionou. Impacto em termos de população, de atividades sociais, econômicas e religiosas que tiveram repercussão para a fixação da população e que contribuiu significativamente na formação do que atualmente é Garopaba. ${ }^{36}$ Demais, a proposta de compra do terreno da Armação revela a elaboração de um projeto de certo vulto, principalmente por agregar uma quantidade expressiva de mão de obra, equipamentos e instalações diversas. Assim, como no caso dos engenhos açucareiros, a produção de óleo de baleia constituiu-se no que poderíamos chamar de verdadeiros complexos industriais, que imprimiam ritmos econômicos, políticos e sociais nas distintas regiões da Colônia.

Fevereiro 25 - Compradas por Manoel Marques Guimarães para a fundação da Armação da pesca de baleias em Garopaba 924 braças de frente com 1500 de fundos de terras, a 500,800 e 1200 réis, termo médio de braça de frente 1073 réis, ou pouco mais de dois por três braças quadradas, ou ainda por uma braça quadrada 0,7 do real. Manoel Marques Guimarães. ${ }^{37}$

A citação acima é mencionada como de autoria de Manoel Marque Guimarães, - incumbido de adquirir as terras para a instalação e desenvolvimento das atividades na Armação Baleeira de Garopaba. Ressalta-se também a "Provisão do Excelentíssimo D. José Joaquim Justiano Mascarenhas Castelbranco", Bispo do Rio de Janeiro, concedendo aos contratadores gerais do contrato da pescaria de baleias em Garopaba um Oratório particular, por um ano inteiro, em Desterro, em 11 de fevereiro de 1896 por Chagas, talvez o Vigário da Vara. Visitada em 21 de março de 1796 pelo vigário, encomendado da Freguesia de Nossa Senhora do Rosário da Enseada de Brito - Ignácio Francisco Xavier dos Passos: em três de agosto de 1796 visitado pelo visitador Mendes. ${ }^{38}$ Do mesmo autor, ainda referimos o benzimento dos paramentos da Capela em 02/03/1796; a Provisão para Vigário em 30/01/1796 e as visitas realizadas pelos Vigários da Freguesia da Enseada de Brito e Freguesia de Sant'Ana, localizada em Vila Nova à Capela da Armação de Garopaba, citados em várias passagens da obra. ${ }^{39}$ No mais, no livro de José Artulino Besen é citada uma visita de Bento Corte de Toledo, em 1799, "Visitador do Continente Sul", a serviço do Bispo do Rio de Janeiro, do qual se transcreve um trecho:

O Visitador Apostólico Pe. Bento Cortes assim se refere à Freguesia de Enseada de Brito: 'Ereta em 1775, com 208 fogos e com 1021 almas de confissão e comunhão. Esta Igreja só tem a Irmandade do Santíssimo, sem compromisso. Tem a Capela da Armação de Garopaba, de invocação de São Joaquim, distante 4 léguas. ${ }^{40}$ 
Este breve relato permite inferir que a Capela, visitada pelo padre Bento, pertencia à Armação Baleeira. Foi esta edificação a que veio a se tornar a matriz da paróquia de Garopaba criada em 1830. Nesse mesmo tempo, a Armação Baleeira de Garopaba foi utilizada com frequência como base de apoio para idas e vindas de tropas militares, comandantes e mesmo de autoridades. Para que se tenha uma ideia da forte presença militar na Armação, destaca-se aqui algumas citações organizadas por Santos Silva:

1808 - Outubro 9 - Chegara aqui (Garopaba) 3 Companhias do Regimento da Terra (Santa Catarina) em marcha para o Rio Grande, continuando em 10 a marcha para Imbituba receberam ordem do Brigadeiro Curado em Maldonado para a suspenderem e se recolheram a esta Armação (de Garopaba) onde estiveram até 18, seguiram para Laguna, donde voltaram, chegaram aqui em 7 de novembro e em 8 seguiram para Ilha. Manoel Marques Guimarães. (...) 1815 - Janeiro 3 - Chegou aqui (Garopaba) a tropa de São Paulo, que segue para Porto Alegre constando de 630 praças, comandadas pelo Tenente Coronel Lázaro José Gonçalves, Sargento-Mor José Pedro Galvão, Mandante Antonio César da Silva e 10 oficiais, acompanhavam 18 cofres com 24 contos pertencentes Fazenda Real e 10 cofres pertencentes ao Regimento; seguiram em 4. Manoel Marques Guimarães. ${ }^{41}$

A ligação de Garopaba com a pesca da Baleia, a complexidade da estrutura erigida para atender tal fim e a competição internacional que já marcava a atividade baleeira também chamaria a atenção do viajante inglês James George Semple Lisle, que desatacaria a sua passagem pelo local nas suas memórias "The life of Major J. G. Semple Lisle", publicada em 1799:

Após uma marcha muito difícil e cansativa, alcançamos uma região de pesca de baleias, a cerca de onze ou doze léguas da Ilha de Santa Catarina, pouco depois do pôr de sol. Ali fomos amavelmente recebidos pelo superintendente, que parecia ser um homem inteligente e que habitava uma ótima casa, a melhor que eu já havia visto na zona do campo. Ele nos mostrou todos os engenhos e prédios que pertenciam àquele lugar. Das queixas que ele fez contra os baleeiros Britânicos, pareceu-nos que ali se faziam sentir grandemente os efeitos do empreendimento e da atividade dos nossos companheiros. ${ }^{42}$

Lisle não menciona, mas é provável que o superintendente a que se refere seja Manoel Marques Guimarães. Há que se ter em conta, há longa 
permanência do superintendente na Armação. A sua chegada em Santa Catarina teria se dado por volta de 1791 quando foi nomeado comandante da Freguesia do Ribeirão da Ilha. Em 1795, já se encontra na Freguesia da Enseada de Brito, como capitão e administrador da Armação Baleeira de Garopaba e seu suplemento em Imbituba. A sua carreira militar prosseguiu até 1816, quando é reformado no posto de Sargento-Mor. Foi proprietário de escravos e tinha intensa participação na vida social e religiosa da Freguesia da Enseada e mesmo na Ilha de Santa Catarina. Sabe-se que Manoel Marques Guimarães foi padrinho de inúmeros batizados e casamentos segundo consta nos livros de registro da Igreja da Enseada. ${ }^{43}$

Como lembra Walter Piazza"4, as "Memórias" de Manoel Marques Guimarães", ganham relevo por apresentar dados sobre a população de Santa Catarina de 1797, além de informações sobre os movimentos portuários e das embarcações que deram entradas e saídas do porto do Rio de Janeiro para os portos catarinenses. Piazza também destaca uma "Memória" escrita em 1818. Nela, sobressaem-se os dados sobre a população de Santa Catarina, cujo total indicado era de 42.604 almas em 3.194 fogos, sem precisar o ano. ${ }^{45}$ Mas, um homem daquele tempo, Henrique Boiteux faria em sua obra "Vida Marítima" menção a Manoel Marques Guimarães como cronista e administrador da Armação Baleeira de Garopaba. Manoel Marques Guimarães é citado como colaborador das informações publicadas no livro em vários trechos. Na mesma obra é veiculada a data em que Marques Guimarães deixa a administração da Armação de Garopaba, 28 de setembro de 1919, e publica a informação sobre o seu falecimento e sepultamento na Capela da Armação em 18/12/1824. As informações ainda que insuficientes permitam inferir que Manoel Marques Guimarães permaneceu como administrador da Armação Baleeira de Garopaba de 1795 a $1819 .{ }^{46}$

No que diz respeito à Garopaba, esses homens foram testemunhas de diferentes períodos da atividade de produção de óleo de baleia. Mais ainda: apresentam em seus discursos e memórias as mudanças decorrentes tanto do funcionamento quanto da crise que atingiria essa atividade econômica. As suas ideias e relatos demonstram uma forte imbricação entre a Armação e a consolidação de um núcleo populacional estável. Assim, como aclara paulatinamente a importância do desenvolvimento de atividades voltadas para o mercado interno, gerando um impacto crucial no desenvolvimento de atividades que gravitavam em um primeiro momento ao seu redor. A partir daí, entende-se as constantes interferências nos anos de crise da atividade.

De qualquer forma, o final do Contrato de pesca das baleias em 1801 também marcou o fim do monopólio da pesca das baleias no Brasil. Como não houve arrematação ou venda das Armações, incluindo a de Garopaba, as mesmas ficaram sob a administração da Fazenda Nacional até 1816. Destacase o período de 1816-1817 pelo fato de se reunir um conjunto de documentos 
que permitem um olhar mais abrangente sobre atividades que se realizaram na Armação Baleeira de Garopaba. Em 1816, as atividades relacionadas à pesca da baleia no Brasil recebem um impulso visando o seu reerguimento. A empresa Siqueira e Lima estabeleceu um contrato com o Governo para administrar as Armações Baleeiras do Rio de Janeiro à Santa Catarina, inclusive Garopaba.

Dentre os inúmeros documentos sobre a armação destacam-se os recibos, relação de baleias pescadas e o contrato da pesca das baleias e propostas de arrematação. Os recibos, que contêm na sua descrição a indicação do ano da pesca da baleia, o nome da pessoa que recebeu os valores, o tipo de atividade realizada, o local onde ocorreu a atividade, os valores recebidos e a respectiva assinatura atestando o recebimento. Todos os recibos são datados de 31/12/1816. Parecem indicar que eram pagamentos relativos a débitos acumulados. As atividades mencionadas nos recibos eram principalmente as de: Remeiro (48); Timoneiro (7) e Arpoador (4). Entre os Remeiros são identificados 11 escravos. Na grande maioria dos recibos os pagamentos se referem às atividades realizadas na Armação de Garopaba e na Armação da Piedade de forma conjunta. Os documentos designados como relação de baleias mortas, ao que parece são utilizados para relacionar as baleias mortas por cada tipo de lancha, em que tipo de Armação, os valores que foram pagos e a relação das pessoas que receberam para que assim fosse possível exercer um maior controle das despesas. Este conjunto de documentos, ao que parece, está relacionado ao período que antecedeu a vigência do contrato firmado pela empresa Siqueira e Lima. ${ }^{47}$

Esse corpo documental manuscrito revela a intensa atividade nas Armações e o envolvimento de um expressivo número de pessoas nas lidas da pesca da baleia. Assim, como indicam valores em números que devidamente sistematizados podem fornecer uma ideia sobre a produção das Armações ao tempo que permite perceber uma dimensão relativa à movimentação financeira, sua distribuição entre os trabalhadores e inferir a avaliação da contribuição da atividade baleeira para a economia local, para a melhoria das condições de vida da população e também o fortalecimento das finanças da Coroa, do fortalecimento na ocupação e defesa do território do Brasil Meridional como parte do projeto de garantir a posse do território até a Colônia do Sacramento como se sabe. Os recibos reúnem valiosas informações para se ter uma ideia sobre a dinâmica das Armações Baleeiras e assim contribuem para se dimensionar o papel econômico e social das Armações.

Não se pode deixar de aludir que os Contrato das Baleias detalham as condições estabelecidas para a pescaria das baleias e do seu comércio, as obrigações da Coroa e dos contratantes e os privilégios, fornecendo um quadro geral da atividade baleeira. Bem como a importância que era dada pela Coroa como uma fonte de renda para o custeio de inúmeras atividades. O Contrato expressa um documento que traduz um conjunto de regras que regulavam 
as relações e condições como também o reconhecimento da importância da indústria baleeira.

Deve-se igualmente considerar os documentos relacionados às propostas de arrematação das Armações são documentos emitidos após 1801, quando foi extinto o monopólio da pesca da baleia. Embora marquem um momento de declínio econômico, revelam as dificuldades dos ocupantes dos cargos da burocracia do Reino em colocar em prática o fim do monopólio. Além disso, destacam novos fatores, como as resistências para que as propostas apresentadas pudessem ser aceitas e assim viabilizar a pesca das baleias de forma livre e concorrente. O poderio desses contratadores seria tal monta que as propostas apresentadas não foram aceitas e as Armações passaram a ser administradas pela Fazenda Real. Na prática, essa passagem para a gestão direta da Coroa Portuguesa levou a decadência da pesca das baleias e a dilapidação do seu patrimônio. Nesse sentido, os documentos referentes à Armação Baleeira de Garopaba e ao período 1816-1817 permitem inferir aspectos das demandas e da movimentação econômica e demográfica que o esforço de reativar a indústria baleeira implicou e sua repercussão no cotidiano da população de Garopaba.

Os dados deste conjunto documental retratam, em parte, as atividades promovidas pela empresa Siqueira e Lima que objetivava dinamizar a indústria baleeira no Brasil. Assim, a Empresa investiu na recuperação das Armações, na contratação de pessoal, na compra de embarcações para tornar viável a pesca das baleias e o seu processamento, como indicam os recibos e a relação de material enviado para a Armação de Garopaba. Mas, principalmente, permitem também perceber o aumento da população de Garopaba, o incremento em suas atividades produtivas e, consequentemente, a melhoria das condições de vida para os seus habitantes.

Não obstante a escassez de documentos para o período após a reativação nas atividades na Armação de Garopaba, ${ }^{48}$ em 1820, passou por Garopaba o naturalista francês August de Saint-Hillaire. Como se pode captar no trecho citado abaixo, o depoimento de Saint- Hillaire atesta o funcionamento, além de descrever aspectos das estruturas e asseverar a importância econômica da Armação para a Região.

Ao chegar a Santa Catarina eu havia pedido a D. Diogo que me arranjasse uma lancha para me levar até a Armação de Garupava ou Garupaba (...)depois de termos atravessado a barra eu me estendi no fundo do barco e dormi, só acordando quando chegamos, às duas horas da manhã, à Armação de Garupava (do guarani "ygacupa", enseada dos barcos). $\mathrm{O}$ barco foi atracado ao trapiche. O patrão me convidou para descer a terra e passar o resto da noite em sua casa. Como estivesse fazendo muito frio, aceitei o convite. Sua mulher colocou uma esteira no chão, para mim, e eu me 
deitei. Levantei-me ao romper do dia e fui providenciar o desembarque de minhas coisas. O administrador da armação, ao qual eu havia sido recomendado, achava-se ausente. $\mathrm{O}$ seu substituto alojou-me num quarto grande e muito ruim, desprovido de móveis e cheio de goteiras. De volta à armação, fui visitar o administrador geral, que tinha chegado durante a minha ausência De fato, a acolhida que ele me fez foi muito fria, para não dizer desdenhosa, e embora o tempo não estivesse quente ele não me convidou para entrar em sua casa, nem me fez a menor amabilidade. Embora a Armação de Pesca de Garupava não fosse destituída de importância, os prédios que a compunham eram bem menores do que os de Itapocoróia e a vista ali bem menos aprazível. A armação fica localizada no fundo de uma enseada estreita e comprida, cercada dos dois lados por morros cobertos de matas de um verde sombrio. A paisagem, de um modo geral bastante monótona, é, entretanto, enfeitada por algumas colinas situadas no continente, mas que, por uma curiosa ilusão de óptica, parecem duas ilhas separadas por um canal. A armação não ficava localizada exatamente no meio da enseada; a igreja, o prédio da administração e os alojamentos do capelão e dos feitores tinham sido construídos a meia-encosta de um morro cujo topo era coberto de matas; o engenho de frigir, os reservatórios e os alojamentos dos negros ficava situado à beira da água. Parti de Garupava no dia 21 de maio, com minhas três carroças. ${ }^{49}$

As atividades da pesca da baleia em Garopaba de acordo com a pesquisa realizada se estendem até 1824 cujas informações sobre a Armação de Garopaba são escassas. Destaca-se do texto de Ellis ${ }^{50}$ que, em 1827, o coronel João Xavier de Souza ficou como depositário da Armação e que, em 1837, ela foi arrematada por Manoel Francisco de Souza Medeiros. Outra informação colhida, consta da Memória, escrita por Melo e Alvim ${ }^{51}$, a qual descreve a condição de abandono das Armações existentes em Santa Catarina. Além disso, Alvim apresentava a proposta de criação da Freguesia de Garopaba, como alternativa para o aproveitamento das suas instalações e estimulo para manter a população ali instalada. Não obstante tal defesa, a proposta de elevação de Garopaba à condição de Freguesia só foi apresentada em 1827, concretizando-se em 1830.

\section{Considerações finais}

A Armação Baleeira de Garopaba deve ser considerada justamente enquanto uma das unidades complexas destinada à caça e ao processamento da 
baleia que se espraiaram pelo litoral do Brasil. Mas, por outras razões já expostas anteriormente, importa lançar um olhar mais detalhado sobre os impactos locais desses empreendimentos. Certo é que a Armação desempenhou a partir de sua instalação e funcionamento um papel relevante no processo de ocupação e formação de Garopaba, principalmente quando se considera o conjunto de edificações, de atividades e de uma população ali fixada. Certamente, possui aspectos de particular interesse para essa História Regional: o processo de ocupação do território em Garopaba e região com a implantação da Armação; a fixação e o aumento da população local após 1793-95; a produção e circulação de bens relacionados direta e indiretamente com a pesca da baleia; a ampliação e dinamização das atividades religiosas e sociais no seu entorno; o fortalecimento do lugar como ponto de conexão com outras regiões para aguada, repouso e desenvolvimento da pesca e seu escoamento e produção agrícola (farinha de mandioca e pescado em especial), em especial Laguna, Rio Grande do Sul e Ilha de Santa Catarina; e como local de passagem e de repouso para viajantes e tropas militares para a defesa do território.

De fato, pode-se considerar que a criação da Freguesia da São Joaquim de Garopaba em 1830 e, sua efetiva instalação em 1846, vinculou-se diretamente à movimentação social, religiosa e econômica existente na Armação Baleeira. Como já foi discutido, para além das referências ao contexto de vinculação das Armações ao Império Português, elas incitaram obras de toda sorte, um processo de diversificação econômica, um aumento populacional expressivo, dentre outras mudanças no contexto local, que acabaram por ensejar questões que extrapolaram o fornecimento de óleo de baleia. Ora, nesse sentido, a formação e o desenvolvimento de núcleos populacionais e suas conexões com a atividade baleeira devem ser consideradas por seus traços originais. Ou melhor, a sua análise possibilita compreender as particularidades e similitudes de uma complexa rede de atividades econômicas que fomentaram processos de ocupação e, igualmente, o comércio interno de gêneros diversos na Colônia Portuguesa.

\section{Notas}

1 SALVADOR, Frei Vicente do. História do Brasil (1550-1627). Belo Horizonte: Editora Itatiaia, 1982, p. 396-397.

2 Destacam-se nesse caso os trabalhos de: ELLIS, Myriam. A Baleia no Brasil Colonial. São Paulo, Edições Melhoramentos/Edusp, 1969; COMERLATO, Fabiana. Análise Espacial das Armações Catarinenses e suas Estruturas Remanescentes: um estudo através da arqueologia histórica. Pontifícia Universidade Católica do rio Grande do Sul, Porto Alegre, 1998; CASTELLUCCI JUNIOR, Wellington. Caçadores de baleia: armações, arpoadores, atravessadores e outros sujeitos envolvidos nos negócios do cetáceo no Brasil. $1^{\text {a }}$. ed. São Paulo: Annablume, 2009 
3 SAINT-HILAIRE, Auguste. Viagem a Curitiba e Província de Santa Catarina. São Paulo: Companhia Editora Nacional, 1936, p. 161.

4 ELLIS, Op. Cit., p. 59.

5 CASTELLUCCI JUNIOR, Op. Cit., p. 28.

6 ELLIS, Op. Cit., p. 26.

7 Ibid., p. 61.

8 Ibid., p. 37.

9 DIAS, Camila Baptista. Escravos e Senhores: as relações socioeconômicas no interior da Freguesia de Nossa Senhora do Bonsucesso de Piratininga (1670-1730). Monografia de fim de curso apresentada ao Departamento de História da UFF. Niterói, 2006.

10 ELLIS, Op. Cit., p. 60.

11 Ibid., p. 41.

12 COMERLATO, Op. Cit., p.59.

13 BOITEUX, Lucas Alexandre. A vida Marítima Catarinense. Cap. XV: A pesca da baleia. O Estado. 10/10/1916 - 28/10/1916.

14 SILVA, Célia Maria e. Ganchos (SC): ascensão e decadência da pequena produção mercantil pesqueira. Florianópolis: UFSC, 1992.

15 CASTELLUCCI JUNIOR, Op. Cit., p. 38-39.

16 DIAS, Op. Cit., p. 57.

17 ELLIS, Op. Cit., p. 127.

18 MENDONÇA, Leila Lobo de. Reflexos da cidade: A Iluminação Pública na Cidade do Rio de Janeiro. Rio de Janeiro: Centro da Memória da Eletricidade no Brasil, 2004.

19 ELLIS, Myriam. Aspectos da pesca da baleia no Brasil Colonial. XIV Coleção da Revista de História. São Paulo, 1958.

20 SILVA, José Gonçalves dos Santos. Subsídios para a história da província de Santa Catarina. Florianópolis: IHGSC, 2007.

21 BRITO Paulo José Miguel de. Memória Política sobre a Capitania de Santa Catarina. Florianópolis: IHGSC, 1952.

22 BOITEUX, Lucas Alexandre. A pesca da baleia. Revista Trimestral do Instituto Histórico Geográfico de Santa Catarina. Florianópolis: Typ da Escola dos Artificies, v.3, 1914, p. 4-16.

23 BESEN, José Artulino. São Joaquim de Garopaba (recordações da Freguesia 1830-1980). Brusque: Gráfico Mercúrio, 1980, p. 11-12.

24 "Localiza-se ao sul da Ilha de Santa Catarina, situada a $27^{\circ} 5815^{\prime}$ " de latitude e a $48^{\circ} 39$ 36 ", segundo o IBGE.

25 BRITO Paulo José Miguel de. Memória Política sobre a Capitania de Santa Catarina. Florianópolis: IHGSC,1952, p. 18.

26 Ibid., p. 94.

27 FARIAS Vilson Francisco de. A Freguesia da Enseada de Brito: Evolução Histórica-Demográfica no Período de 1778 a 1807. UFSC, 1980. 
28 AHU [post, 1799, novembro, 6, ilha de SC].

29 Na documentação consultada encontram-se alguns manuscritos do Arquivo Histórico Ultramarino, entre os quais destacamos o documento 405 do AHU [post, 1799, novembro, 6, ilha de SC].

30 AHU Doc. 405 [post, 1799, novembro, 6, ilha de SC].

31 AHU Doc. 405 [post, 1799, novembro, 6, ilha de SC]

32 Além disso, o inventário realizado em 1816 reitera as informações acerca de suas dimensões e significado para a ocupação de Garopaba.

33 Arquivo Nacional, Rio de Janeiro - Junta do Comércio, Caixa 360, Real Administração da Pesca da Baleia.

34 Ibid.

35 Ibid.

36 Destaque-se que atualmente se encontram "em pé" a Casa do Administrador e a Igreja São Joaquim que constituíam parte das instalações da Armação de Garopaba.

37 SILVA, Op. Cit., p. 90.

38 Ibid., p. 110.

39 Ibid., p. 102-103.

40 BESEN, Op. Cit., p. 26.

41 Ibid., p. 237.

42 Apud. HARO, Martins Afonso Palma de (org.). Ilha de Santa Catarina; relatos de viajantes estrangeiros nos séculos XVIII e XIX. Florianópolis: ed. da UFSC/ Lunardelli, 1990, p. 123124.

43 FARIAS Vilson Francisco de. A Freguesia da Enseada de Brito: Evolução Histórica-Demográfica no Período de 1778 a 1807. UFSC, 1980.

44 PIAZZA, Walter. Santa Catarina: sua história. Florianópolis: UFSC/Lunardelli, 1983, pp. 308-309.

45 Ibid., p. 308, 318 e 319.

46 SILVA, José Gonçalves dos Santos. Subsídios para a história da província de Santa Catarina. Florianópolis: IHGSC, 2007.

47 Os documentos são: Inventário da Real Armação de São Joaquim de Garopaba, conforme avaliação dos mestres pedreiros Francisco Gonçalves e João Gomes e mestres carpinteiros Joaquim dos Santos e Teixeira Brasil. Descritos em 14 folhas, descrevem de forma detalhada o conjunto de bens da Armação, inclusive os bens do Suplemento da Fábrica de Imbituba; Documentos relacionados à movimentação econômica, em especial recibos, que estão subscritos por Jacinto Correa, Administrador Geral das Armações de Santa Catarina, e por Manoel Marques Guimarães, Administrador da Armação Baleeira de Garopaba. Estes recibos referem-se ao fornecimento de carne, de lenha, de farinha, de sal, a pagamentos do cirurgião, do capelão, e cujos valores ajudam a dar uma dimensão do montante de dinheiro que circulava na Armação; um conjunto documentos extraídos dos jornais existentes na Biblioteca Pública de Santa Catarina, referentes à segunda metade do século XIX e que tratam de notícias relacionadas à Garopaba e que contribuem para perceber aspectos do que ocorriam em Garopaba. Essa documentação foi disponibilizada 
pela professora Beatriz Magnoniam, da Universidade Federal de Santa Catarina, a quem agradecemos imensamente

48 O que se conseguiu foi a informação a respeito da saída de Manoel Marques Guimarães da Administração da Armação, em 28 de setembro de 1819 e a chegada do novo administrador em 1820, como indica Santos Silva. SILVA, José Gonçalves dos Santos. Subsídios para a história da província de Santa Catarina. Florianópolis: IHGSC, 2007, p. 273.

49 SAINT-HILAIRE, Auguste. Viagem a Curitiba e Província de Santa Catarina. São Paulo: Companhia Editora Nacional, 1936.

50 ELLIS, Myriam. Aspectos da pesca da baleia no Brasil Colonial. XIV Coleção da Revista de História. São Paulo, 1958, p. 389.

51 ALVIM, Miguel de Souza Mello. A pesca da baleia em Santa Catarina. Revista Trimestral do Instituto Histórico Geográfico de Santa Catarina. Florianópolis: Typ da Escola dos Artífices, v.3, 1914, p. 86-93.

Recebido em 19/02/2017

Aprovado em 07/06/2018 